\title{
Mass spectrometry identification of the liquor contained in the plum vase excavated from Jurou Li's Grave of the Jin Dynasty (1115-1234 CE) in Xi'an, Shannxi, China
}

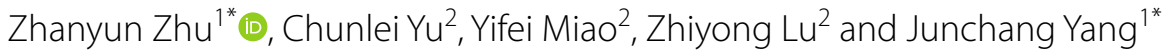

\begin{abstract}
In order to accurately identify the ancient liquid contained in the plum vase excavated from Jurou Li's Grave of the Jin Dynasty (1115-1234 CE) in Xi'an, mass spectrometry was applied to determine the amino acid sequences of the residual proteins extracted from the liquid sample. The sequences were searched against a standard protein sequence database. The proteins extracted was identified as glycosyltransferase from Sorghum bicolor, calcium-dependent protein kinase 2 from Wickerhamomyces ciferrii, and cytochrome b-c1 complex subunit Rieske from Nadsonia fulvescens. These findings indicate that the extremely degraded liquid in the plum vase was made from the cereal of sorghum by alcoholic fermentation of Wickerhamomyces ciferrii and Nadsonia fulvescens, providing direct evidence for liquor in the Jin Dynasty.
\end{abstract}

Keywords: Archaeological chemistry, Mass spectrometry, Fermented beverage, Plum vase, Jin Dynasty

\section{Introduction}

In February 2014, an undisturbed grave with one brick chamber was excavated by Shannxi Provincial Institute of Archaeology [1]. According to the inscription on the unearthed brick tablet, the owner of in the grave is Jurou $\mathrm{Li}$, the highest official of Shannxi province in the Jin Dynasty (1115-1234 CE). A total of 64 objects, including porcelain, bronze, jade etc. were discovered. The most important object among them is a plum vase which has been sealed completely, containing transparent liquid (see Fig. 1).

Plum vase is a general designation of ancient Chinese porcelain with the features of small rim, short neck, broad shoulder, thin base, ringed foot. It is named as the rim is so small that only plum twigs could be inserted in,

\footnotetext{
*Correspondence: zhanyun.zhu@nwpu.edu.cn; yangjunchang@nwpu. edu.cn

${ }^{1}$ Centre for Materials and Conservation Research in Archaeology/ Centre for Nano Energy Materials, State Key Laboratory of Solidification Processing, School of Materials Science and Engineering, Northwestern Polytechnical University, Xi'an 710072, China

Full list of author information is available at the end of the article
}

and it is well-known as a container for liquor $[2,3]$. Thus, it is logically consistent to develop a working hypothesis that the liquid contained in the excavated plum vase was liquor from the Jin Dynasty.

To the best of the authors' knowledge, Chinese liquor is defined as fermented beverage with cereals as raw materials. Hence, the information about both raw material and fermentation is required to determine whether an ancient liquid is liquor or not. It was shown that through chemical, archaeobotanical, DNA analysis of residues, it is possible to understand the original content of ancient fermented beverage [4-20]. Nevertheless, due to disparate preservation conditions of samples from different archaeological background, it is promising to explore the degraded residues of proteins from plants and yeasts related to liquor-making by mass spectrometry, when conventional analytical methods are not applicable.

In this paper, the residual peptides from ancient liquid in the plum vase excavated from Jurou Li's Grave was focused on, as the analyses of small molecules and starch grain did not yield satisfactory results. To recognize the raw material and possible fermentation of the liquid, we 


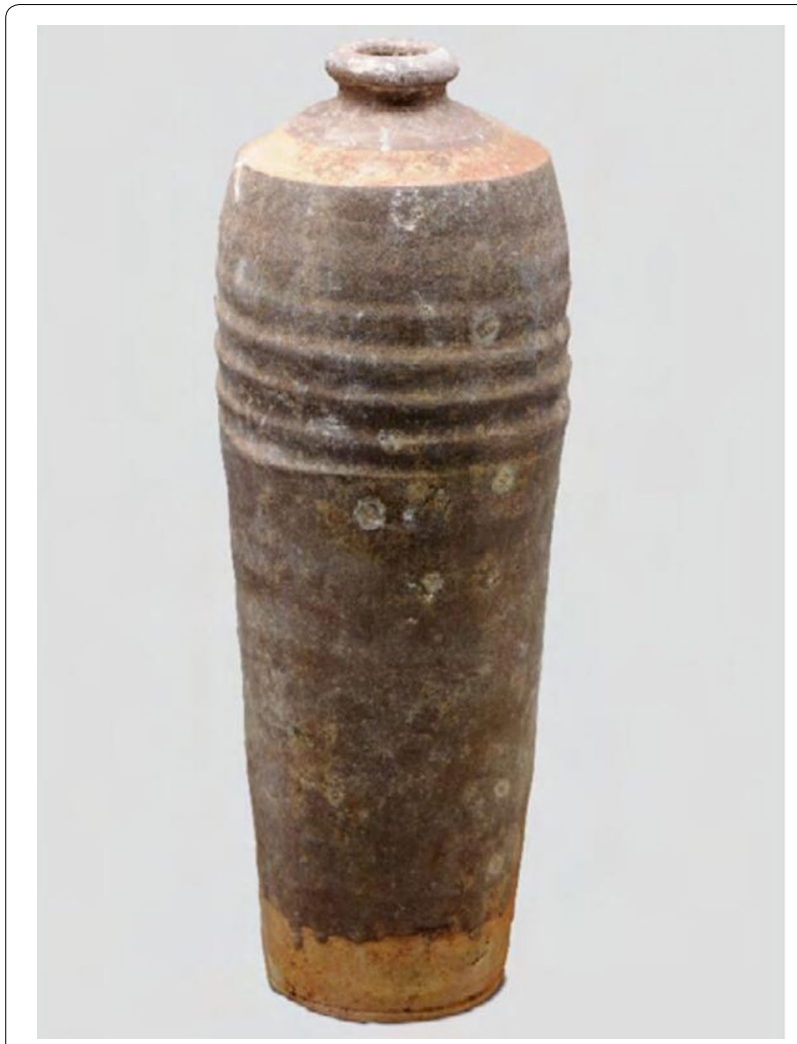

Fig. 1 The plum vase excavated from Jurou Li's Grave of the Jin Dynasty (1115-1234 CE)

applied SDS-PAGE to isolate possible proteins and identified them by means of mass spectrometry.

\section{Materials and methods}

\section{Chemicals and reagents}

1.4-Dithiothreitol (DTT) was obtained from Amresco (USA). Acetonitrile (ACN) was acquired from Fisher (USA). Trifluoroacetic acid (TFA), iodoacetamide, ammonium bicarbonate, and formic acid were supplied by Sigma-Aldrich (USA). Trypsin was purchased from Promega (USA). Deionized water was provided by a Milli-Q Ultrapure water purification system (USA). Vivaspin 500 ultrafiltration devices (3 kDa MWCO) were purchased from GE Healthcare (USA).

\section{SDS-PAGE}

$100 \mu \mathrm{L}$ of liquid was pipetted from the plum vase, desalted and concentrated to $20 \mu \mathrm{L}$ using an ultrafiltration device. Then it was mixed directly with $5 \mu \mathrm{L}$ of SDS-PAGE loading buffer. Sodium dodecyl sulfate polyacrylamide gel electrophoresis (SDS-PAGE) was performed on a continuous buffered system using a precast gel (4-20\%). Before electrophoresis, the sample was heated for $5 \mathrm{~min}$ in boiling water. $20 \mu \mathrm{L}$ of sample was applied to the lane. After completion of an electrophoresis run at $150 \mathrm{~V}$ for $45 \mathrm{~min}$, the gel was removed from the glass plate and stained with $0.25 \%$ Coomassie Brilliant Blue (R-250) for $4 \mathrm{~h}$, and destained with aqueous solution containing $30 \%$ methanol and $10 \%$ acetic acid for $24 \mathrm{~h}$.

\section{In-gel digestion}

The blue-stained area on the gel was cut into small spots of $1 \mathrm{~mm}$ [2], destained with $25 \mathrm{mM} \mathrm{NH} \mathrm{NHCO}_{3}$ and $50 \%$ acetonitrile for two times separately ( $1 \mathrm{~h}$ per time), and dehydrated by the addition of $500 \mu \mathrm{L}$ acetonitrile (100\%). Disulfide bonds were cleaved by incubating the sample for $60 \mathrm{~min}$ at $56{ }^{\circ} \mathrm{C}$ with $200 \mu \mathrm{L}$ DTT $(10 \mathrm{mM})$ in $25 \mathrm{mM} \mathrm{NH}_{4} \mathrm{HCO}_{3}$ buffer. Then alkylation of cysteines was performed by incubation of the sample with $200 \mu \mathrm{L}$ iodoacetamide $(55 \mathrm{mM})$ in $25 \mathrm{mM} \mathrm{NH}_{4} \mathrm{HCO}_{3}$ buffer for $45 \mathrm{~min}$ at room temperature in darkness. And then spots were dehydrated again with $500 \mu \mathrm{L}$ of acetonitrile after washed by $25 \mathrm{mM} \mathrm{NH} \mathrm{HCO}_{3}$ twice. After that, trypsin solution $\left(10 \mathrm{ng} / \mu \mathrm{L}\right.$ in $25 \mathrm{mM} \mathrm{NH} \mathrm{HCO}_{3}$ buffer $)$ was added for $37{ }^{\circ} \mathrm{C}$ overnight digestion which was stopped by addition of $5 \%$ formic acid. Finally, the extracts were dried under the protection of $\mathrm{N}_{2}$, and reconstituted in $3 \mu \mathrm{L}$ of $0.1 \%$ trifluoroacetic acid prior to mass spectrometry analysis.

\section{LC-ESI-MS/MS analysis based on Orbitrap}

After protein digestion, the peptide sample was desalted using a Strata X column (Phenomenex), vacuum-dried and then resuspended in $200 \mu \mathrm{L}$ buffer $\mathrm{A}(2 \% \mathrm{ACN}$, $0.1 \%$ FA). After centrifugation at $20,000 \mathrm{~g}$ for $10 \mathrm{~min}$, the supernatant was recovered to obtain a peptide solution with a final concentration of approximately $0.5 \mu \mathrm{g} / \mu \mathrm{L}$. $10 \mu \mathrm{L}$ supernatant was loaded on a LC-20AD nano HPLC (Shimadzu, Japan) by the autosampler onto a $2 \mathrm{~cm} \mathrm{C18}$ trap column. Then, the peptides were eluted onto a $10 \mathrm{~cm}$ analytical C18 column (inner diameter $75 \mu \mathrm{m}$ ) packed in-house. The sample was loaded at $15 \mu \mathrm{L} / \mathrm{min}$ for $4 \mathrm{~min}$, then the $91 \mathrm{~min}$ gradient was run at $400 \mathrm{~nL} / \mathrm{min}$ starting from 2 to $35 \%$ buffer B (98\% ACN, 0.1\% FA), followed by 5 min linear gradient to $80 \%$, and maintenance at $80 \% \mathrm{~B}$ for $8 \mathrm{~min}$, and finally return to $2 \%$ in $2 \mathrm{~min}$.

The peptides were subjected to nanoelectrospray ionization followed by tandem mass spectrometry (MS/MS) in an LTQ Orbitrap Velos (Thermo Fisher Scientific, USA) coupled online to the HPLC. Intact peptides were detected in the Orbitrap at a resolution of 60,000. Peptides were selected for MS/MS using collision induced dissociation (CID) operating mode with a normalized collision energy setting of $35 \%$. Ion fragments were detected in the LTQ. A data-dependent procedure that alternated between $1 \mathrm{MS}$ scan followed by $10 \mathrm{MS} / \mathrm{MS}$ scans was applied for the ten most abundant precursor 
ions above a threshold ion count of 5000 in the MS survey scan with a following dynamic exclusion settings: repeat counts of 2 , repeat duration of $30 \mathrm{~s}$, and exclusion duration of $120 \mathrm{~s}$. The applied electrospray voltage was $1.5 \mathrm{kV}$. Automatic gain control (AGC) was used to prevent overfilling of the ion trap. $1 \times 10^{4}$ ions were accumulated in the ion trap to generate CID spectra. For MS scans, the $m / z$ scan range was $350-2000 \mathrm{Da}$.

\section{Database search}

Raw data from nano LC-MS/MS analysis was searched against the non-redundant protein database (Uniprot, with Spermatophyta and Fungi as taxonomy restriction) using in-house MASCOT software version 2.3.02 (Matrix Science, USA). Trypsin was chosen as cleavage specificity with a maximum number of allowed missed cleavages of two. Carbamidomethylation (C) was set as a fixed modification, while deamidation (NQ), oxidation (M) and Gln $\rightarrow$ pyro-Glu (N-term Q) as variable modifications. The searches were performed using a peptide mass tolerance of $20 \mathrm{ppm}$ and a fragment mass tolerance of $0.1 \mathrm{Da}$. To determine if a reanalysis step is needed, quality control was performed and the MASCOT e-value was set to below 0.05 . Protein identifications were accepted with at least one unique peptide. All the identified peptides were extracted and BLAST searched against the NCBInr database to check the species-specificity of the sequences.

\section{Results and discussion}

The liquid sample recovered from the plum vase excavated from Jurou Li's Grave was analyzed with the scope of assessing its nature. In our sample, severe deterioration of the content was expected considering the nearly one millennium age of the sample and the critical storage conditions during the amazingly long period in the grave. Chromatography testing of this sample was unsuccessful in determining whether this was liquor, because small molecules such as ethanol, other alcohols and esters have faded away due to their volatility. Trace of degraded residues of proteins has the potential to survive and provide key information for the ancient liquid.

The proposed methodology was based on the capability of mass spectrometry to detect species-specific peptides from proteins, for the objective to identify the origin species of the proteins from ancient and denaturated sample of the liquid contained in the plum vase. It is shown in Fig. 2 that the extraction protocol used here was effective in recovering enough residues of proteins representing the nature of the liquid. However, the weak staining and obvious smearing of the bands along the gel indicated that the protein preserved in the ancient liquid was infinitesimal and highly degraded.

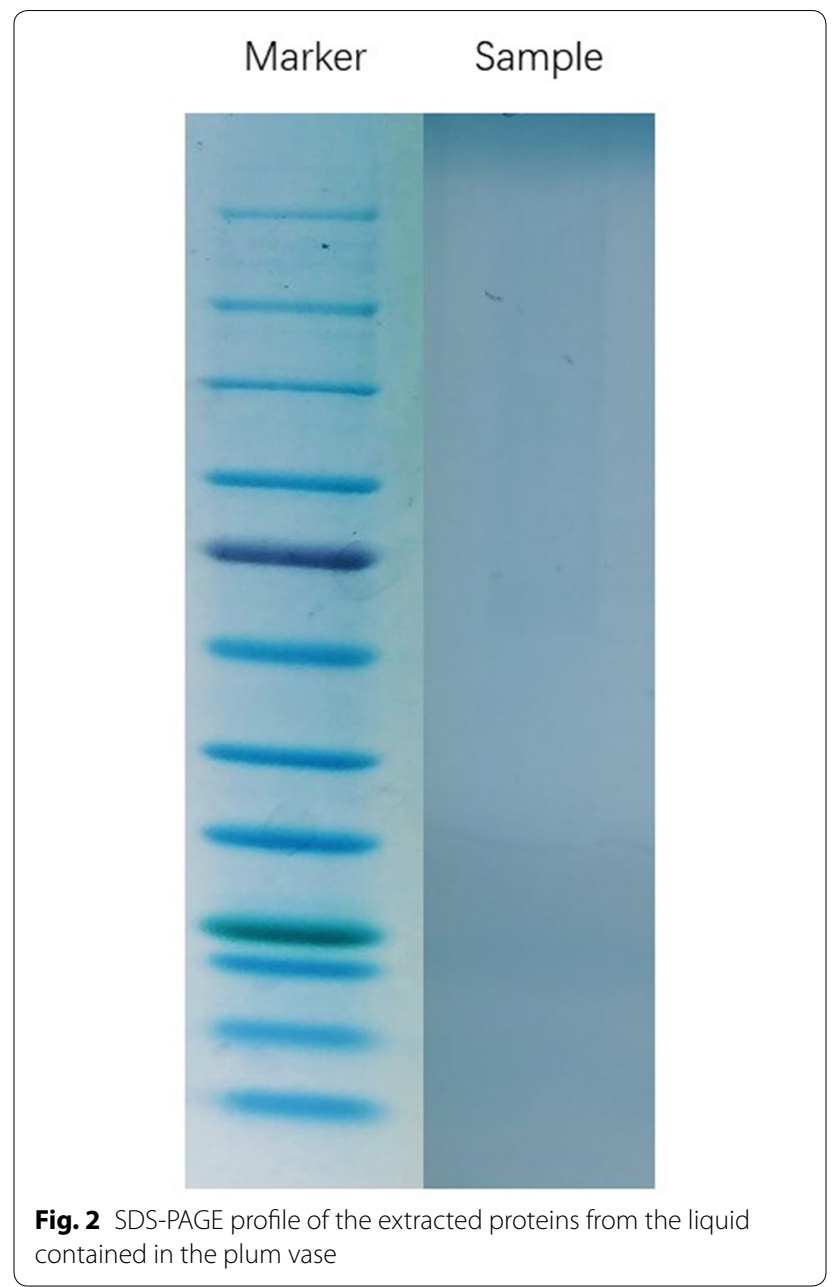

The mass spectrometric approach to properly identify proteins requires that sequences of at least one peptide is determined regardless of the integrity of the full protein. It is presented in Table 1 that three unique peptides were identified from the degraded residues, in which one for Sorghum bicolor glycosyltransferase (SORBI_3001G093100), one for Nadsonia fulvescens cytochrome b-c1 complex subunit Rieske (NADFUDRAFT_81912), and one for Wickerhamomyces ciferrii calcium-dependent protein kinase 2 (BN7_3818).

The analysis of an extra low content of this ancient sample resulted in a set of ions with good signal-to-noise ratio. Particularly, the MS/MS spectra shown respectively in Figs. 3, 4 and 5 allowed the identification of the peptide AGELAERAR in the glycosyltransferase from Sorghum bicolor, peptide SISISGLR in the cytochrome b-c1 complex subunit Rieske from Nadsonia fulvescens, and peptide IILDVK in the calcium-dependent protein kinase 2 from Wickerhamomyces ciferrii. The data is reliable since the $y$ and $b$ ions had good continuity.

In contrast to occidental tradition of wine-making, Chinese liquor is characterized by using cereals as raw 
Table 1 Species unique peptides of proteins identified for the liquid sample analyzed

\begin{tabular}{|c|c|c|c|c|c|c|}
\hline Proteins & Taxonomies & Protein ID numbers & Unique peptides & lons_score & E-value & Modifications \\
\hline Glycosyltransferase & Sorghum bicolor (Sorghum) & $\begin{array}{l}\text { A0A1B6Q131 } \\
\text { (SORBI_3001G093100) }\end{array}$ & AGELAERAR & 60.8 & 0.101787 & \\
\hline $\begin{array}{l}\text { Cytochrome b-c1 complex } \\
\text { subunit Rieske }\end{array}$ & $\begin{array}{l}\text { Nadsonia fulvescens var. } \\
\text { elongata DSM } 6958\end{array}$ & $\begin{array}{l}\text { A0A1E3PRG6 (NADF- } \\
\text { UDRAFT_81912) }\end{array}$ & SISISGLR & 62.61 & 0.000802 & \\
\hline $\begin{array}{l}\text { Calcium-dependent protein } \\
\text { kinase } 2\end{array}$ & $\begin{array}{l}\text { Wickerhamomyces ciferrii } \\
\text { (yeast) }\end{array}$ & K0KQ31 (BN7_3818) & IILDVK & 44.45 & 0.032976 & \\
\hline
\end{tabular}

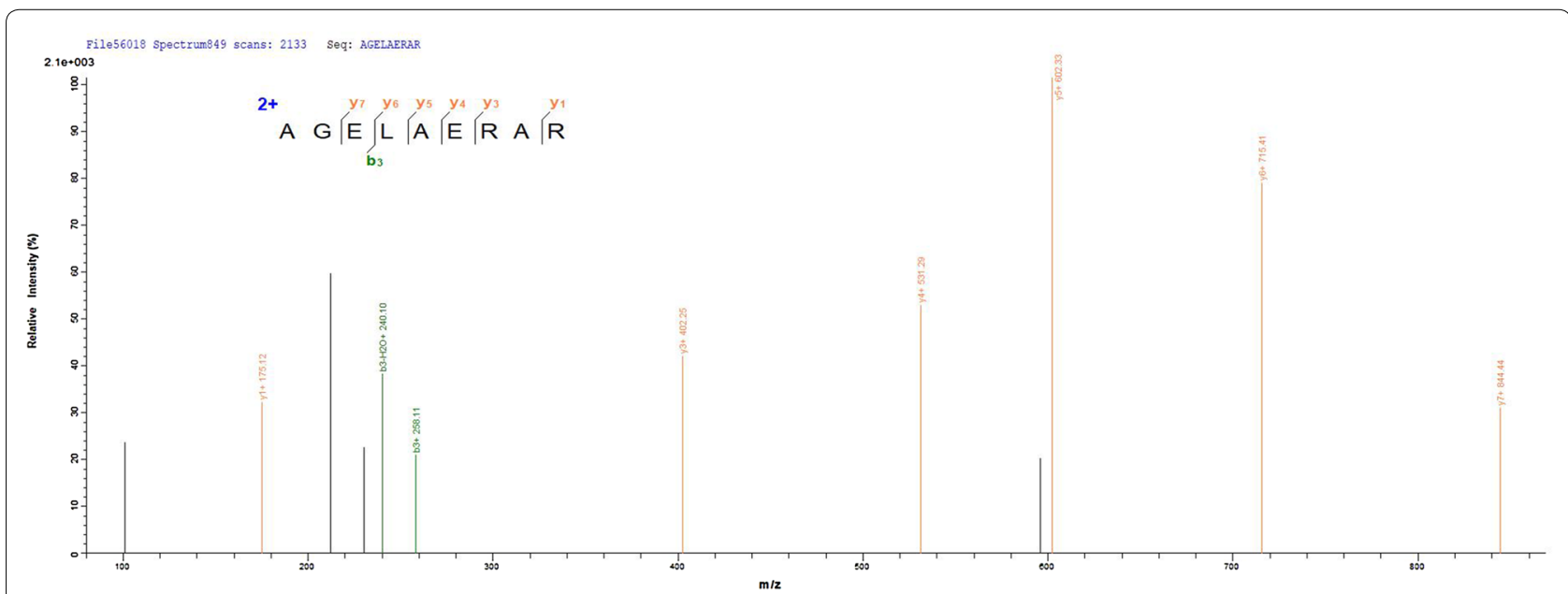

Fig. $3 \mathrm{MS} / \mathrm{MS}$ spectrum of the doubly charged ion at $m / z=486.759$ from the digested extract of the liquid sample from the plum vase and presenting the $y$ and $b$ fragments of the peptide sequence AGELAERAR specific to the glycosyltransferase from Sorghum bicolor

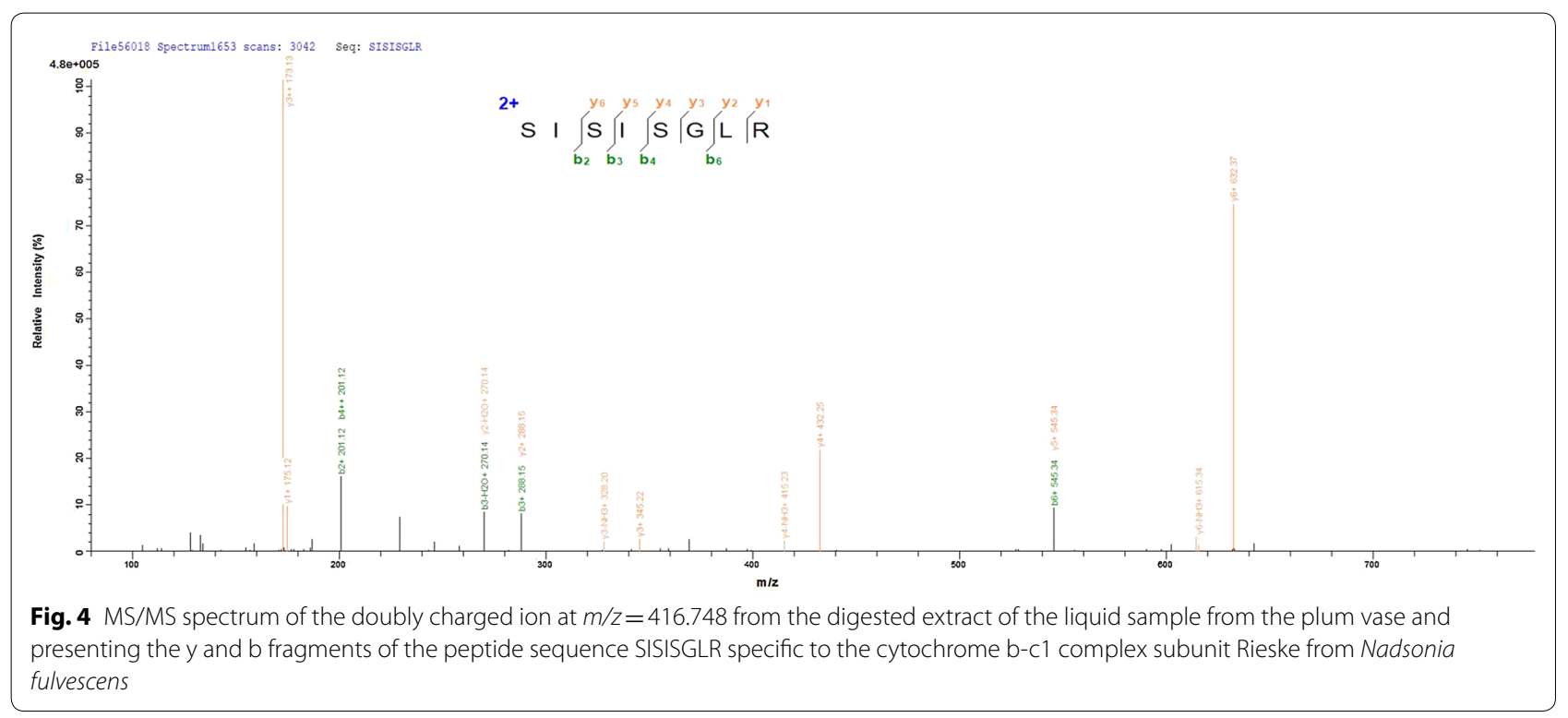




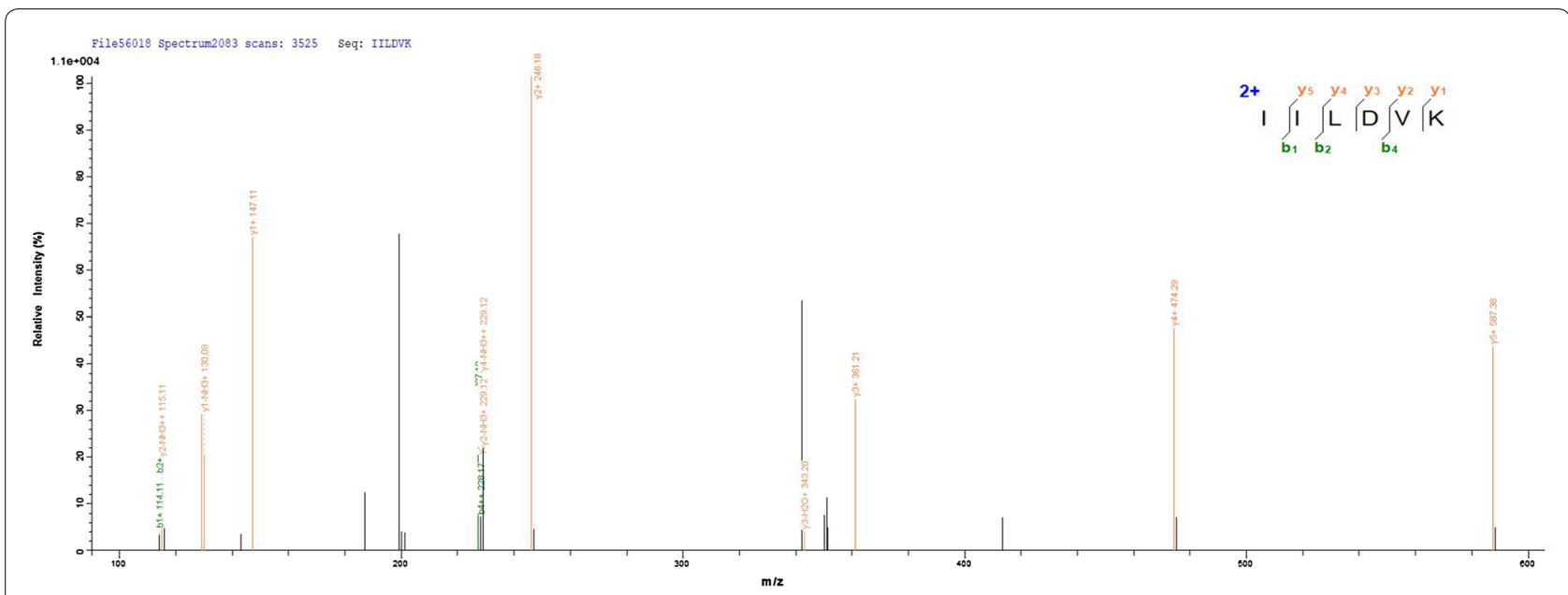

Fig. $5 \mathrm{MS} / \mathrm{MS}$ spectrum of the doubly charged ion at $\mathrm{m} / \mathrm{z}=350.734$ from the digested extract of the liquid sample from the plum vase and presenting the $y$ and $b$ fragments of the peptide sequence IILDVK specific to the calcium-dependent protein kinase 2 from Wickerhamomyces ciferrii

materials including sorghum, barley, wheat, rice, and pea. Among them, Sorghum bicolor was considered as the optimal one [21]. Glycosyltransferase (GT) is ubiquitous in plant cells, transfers nucleotide-diphosphate-activated sugars to low molecular weight substrates [22].

Starch grain extraction and analysis was attempted and showed no relevant result because the micro remains of plants failed to preserve during the long period. The accurate identification of glycosyltransferase from Sorghum bicolor by mass spectrometry indicated that the liquid contained in the plum vase was probably beverage made from Sorghum bicolor.

Yeasts play a significant role in liquor making, as they are the key to alcoholic fermentation. It has been reported that both Wickerhamomyces ciferrii and Nadsonia fulvescens are good candidates for alcoholic fermentation, with the ability to produce by-products of aromas and fusel alcohols [23-25]. Furthermore, Wickerhamomyces ciferrii was identified in a traditional rice wine in India [26]. The evidence of both yeast and cereal proteins existed in the sample converge to support the hypothesis that the liquid contained in the plum vase was indeed ancient liquor. In detail, fermentation of Sorghum bicolor cereal by mediation of Wickerhamomyces ciferrii and Nadsonia fulvescens can be inferred.

How many peptides could represent a reliable identification of a protein? It is still an open question concerning the guidelines for peptide and protein identification data [27]. Recent publication in top journals on proteomics showed that proteins could be unequivocally identified with at least one unique peptide $[28,29]$. Since the sample in this work is extremely degraded in archaeological context, adopting the above threshold could reveal more solid information. The plum vase containing the liquid sample was intactly sealed, reducing the probability of contamination. Moreover, ancient literature recorded that porcelain of this style tended to be used for storage of liquor [30-32]. Therefore, despite the low amount of sample analyzed, the developed methodology succeeded in identifying the liquor contained in the excavated plum vase.

\section{Conclusions}

Plum vase is a prevalent style of vessel among all strata since the Tang Dynasty (618-907 CE). It was successfully demonstrated that the one excavated from Jurou Li's Grave of the Jin Dynasty was used for liquor storage. This study constitutes the first accurate identification of the liquid contained in excavated plum vase, reveals key information about the raw material and fermentation of the ancient Chinese liquor, provides scientific basis for the function of plum vase. Also, it is shown that the adopted technical process was efficient in regarding accurate identification of the origin species of cereal and yeast in liquor-making from complex matrix containing very low amounts of residues.

\section{Authors' contributions}

ZZ carried out the experiments and drafted the manuscript. CY and YM conducted the excavation and discussion of the results. ZL and JY participated in the experimental design. All authors read and approved the final manuscript.

\section{Author details \\ ${ }^{1}$ Centre for Materials and Conservation Research in Archaeology/Centre for Nano Energy Materials, State Key Laboratory of Solidification Processing, School of Materials Science and Engineering, Northwestern Polytechnical University, Xi'an 710072, China. ${ }^{2}$ Shannxi Provincial Institute of Archaeology, Xi'an 710000, China.}

\section{Acknowledgements}

This work is supported by China Postdoctoral Science Foundation (2017M613197, 2018T111093), Northwestern Polytechnical University 
(31020170QD009), and National Natural Science Foundation of China (51674206).

\section{Competing interests}

The authors declare that they have no competing interests.

\section{Publisher's Note}

Springer Nature remains neutral with regard to jurisdictional claims in published maps and institutional affiliations.

Received: 5 June 2018 Accepted: 18 July 2018

Published online: 31 July 2018

\section{References}

1. Shannxi Provincial Institute of Archaeology. Brief report on the excavation of Jurou Li's grave in Xi'an, Shannxi, in the Jin Dynasty. Archaeol Cultur Relics. 2017;2:40-9.

2. Mu B. Plum vase and winebottle. Cultur Relics South China. 2013;1:188-93.

3. Li L. Shape features of plum vases in song dynasty. J Ceram. 2012:4:534-8.

4. McGovern PE, et al. Fermented beverages of pre-and proto-historic China. Proc Natl Acad Sci USA. 2004;101:17593-8.

5. McGovern PE, Mirzoian A, Hall GR. Ancient Egyptian herbal wines. Proc Natl Acad Sci. 2009;106:7361-6.

6. McGovern PE, Hall GR. Charting a future course for organic residue analysis in archaeology. J Archaeol Method Theory. 2016;23:592-622.

7. Jeandet $P$, et al. Chemical messages in 170-year-old champagne bottles from the Baltic Sea: revealing tastes from the past. Proc Natl Acad Sci. 2015:112:5893-8.

8. Foley BP, Hansson MC, Kourkoumelis DP, Theodoulou TA. Aspects of ancient Greek trade re-evaluated with amphora DNA evidence. J Archaeol Sci. 2012;39:389-98.

9. Stern B, Heron C, Tellefsen T, Serpico M. New investigations into the Uluburun resin cargo. J Archaeol Sci. 2008;35:2188-203.

10. Romanus $K$, et al. Wine and olive oil permeation in pitched and nonpitched ceramics: relation with results from archaeological amphorae from Sagalassos, Turkey. J Archaeol Sci. 2009;36:900-9.

11. Pecci A, Ontiveros MÁC, Garnier N. Identifying wine and oil production: analysis of residues from Roman and Late antique plastered vats. J Archaeol Sci. 2013:40:4491-8.

12. Pecci A, Giorgi G, Salvini L, Ontiveros MÁC. Identifying wine markers in ceramics and plasters using gas chromatography-mass spectrometry. Experimental and archaeological materials. J Archaeol Sci. 2013:40:109-15

13. Milanesi C, Bigliazzi I, Faleri C, Caterina B, Cresti M. Microscope observations and DNA analysis of wine residues from Roman amphorae found in Ukraine and from bottles of recent Tuscan wines. J Archaeol Sci. 2011;38:3675-80.
14. Guasch-Jané MR, Ibern-Gómez M, Andrés-Lacueva C, Jáuregui O, Lamuela-Raventós RM. Liquid chromatography with mass spectrometry in tandem mode applied for the identification of wine markers in residues from ancient Egyptian vessels. Anal Chem. 2004;76:1672-7.

15. Guasch-Jané MR, Andrés-Lacueva $C$, Jáuregui $O$, Lamuela-Raventós RM. First evidence of white wine in ancient Egypt from Tutankhamun's tomb. J Archaeol Sci. 2006;33:1075-80.

16. Barnard H, Dooley AN, Areshian G, Gasparyan B, Faull KF. Chemical evidence for wine production around 4000 BCE in the Late Chalcolithic near eastern highlands. J Archaeol Sci. 2011;38:977-84.

17. Arobba D, et al. Palaeobotanical, chemical and physical investigation of the content of an ancient wine amphora from the northern Tyrrhenian sea in Italy. J Archaeol Sci. 2014;45:226-33.

18. Wang J, et al. Revealing a 5,000-y-old beer recipe in China. Proc Natl Acad Sci. 2016;113:6444.

19. Zlateva B, Rangelov M. Chemical analysis of organic residues found in Hellenistic time amphorae from SE Bulgaria. J Appl Spectrosc. 2015:82:221-7.

20. Michel RH, McGovern PE, Badler VR. The first wine and beer. Anal Chem. 1993:65:408A-13A.

21. Li Y. Sorghum bicolor is the optimal raw material in Chinese liquor making. Liquor Making. 1990;6:1-4.

22. Vogt T, Jones P. Glycosyltransferases in plant natural product synthesis: characterization of a supergene family. Trends Plant Sci. 2000:5:380-6.

23. Contreras A, et al. The application of non-Saccharomyces yeast in fermentations with limited aeration as a strategy for the production of wine with reduced alcohol content. Int J Food Microbiol. 2015;205:7-15.

24. Gamero A, et al. High-throughput screening of a large collection of nonconventional yeasts reveals their potential for aroma formation in food fermentation. Food Microbiol. 2016;60:147-59.

25. Gonçalves $C_{\text {, }}$ et al. Evidence for loss and reacquisition of alcoholic fermentation in a fructophilic yeast lineage. eLife. 2018;7:e33034.

26. Bora SS, Keot J, Das S, Sarma K, Barooah M. Metagenomics analysis of microbial communities associated with a traditional rice wine starter culture (Xaj-pitha) of Assam, India. 3 Biotech. 2016;6:153.

27. Leo $\mathrm{G}$, et al. Proteomic strategies for the identification of proteinaceous binders in paintings. Anal Bioanal Chem. 2009;395:2269-80.

28. Chen J, et al. iTRAQ and RNA-Seq analyses provide new insights into regulation mechanism of symbiotic germination of Dendrobium officinale seeds (Orchidaceae). J Proteome Res. 2017;16:2174-87.

29. Zhu X, et al. Tissue-specific proteogenomic analysis of Plutella xylostella larval midgut using a multialgorithm pipeline. Mol Cell Proteomics. 2016;15:1791-807.

30. Xu L. The origin and development of plum vase. Ceram Stud J. 2001;16:41-4.

31. Wang J. Change of shape: the history makes the vase. Collections. 2017:4:136-46.

32. Yao J. Discussion on the function of ancient Chinese plum vases. Jingdezhen's Ceram. 2018:1:4-5.

\section{Submit your manuscript to a SpringerOpen ${ }^{\circ}$ journal and benefit from:}

- Convenient online submission

- Rigorous peer review

- Open access: articles freely available online

- High visibility within the field

Retaining the copyright to your article

Submit your next manuscript at springeropen.com 